\title{
Confrontation and Cooperation: The hidden history of national parks and indigenous groups in Canada
}

\author{
Christian Isbister
}

This paper involves an analysis of histories of national parks in Canada, specifically the changing relationship between Parks Canada and Indigenous groups. A specific examination of the history of Banff National Park and Riding Mountain National Park demonstrates that the economics of sport hunting and tourism, not conservationism, was the major contributor to the creation of these parks. In addition, it highlights the ways in which Canadian national parks erased or coopted the legacies of Indigenous groups who previously inhabited the region. However, in examining attention to the recent moose culling in Cape Breton Highlands National Park one can see a shift in policy towards cooperation that allows Parks Canada to maintaining maintain national parks while simultaneously respecting the hunting rights of Indigenous groups. This would demonstrate a shift in official policy towards recognition of Indigenous rights and reconciliation for past injustices committed.

National parks appear to have a wide appeal to Canadians, which aligns with the relatively recent push for conservation of our natural landscape. As centers for tourism and relaxation, these areas also become important centers for the economic development of the surrounding region. However, almost no coverage has ever been given to the racist and often times overtly authoritarian ways that the Canadian government acquired the land with which to create national parks. In the past, various branches of government used coercive or directly oppressive means to remove land that had been given to Indigenous groups. The failure to consult with these Indigenous populations is shown most overtly in the Riding Mountain National Park and Banff National Park regions, although these two areas are indicative of a wider attempt to eliminate the stories of native americans to preserve the illusion of a pristine natural environment otherwise untouched by man. However, contrary to this the recent approach taken in the Cape Breton moose culling in the Highlands National Park is perhaps emblematic of a new approach to address historical injustices and protect Indigenous rights. This paper will therefore examine the gradual shift in official policy towards Indigenous groups and national parks through the specific examples of Riding Mountain National Park and the Keeseekoowenin, Banff National Park and the Stoney Nakoda People, and finally Highlands National Park and the Nova Scotia Mi'kmaq. 
Ultimately, this paper will argue there has been a gradual shift from an oppositional relationship towards cooperation.

Riding National Park was established in 1930 as one of the earliest national parks in Canada. ${ }^{1}$ However, it is important to note that the creation of areas such as these was not solely the product of the state, but instead a "convergence of local and state interests - tourism promotion, game protection and the assimilation of Native hunters" that would ultimately force the Keeseekoowenin, a member of the Ojibway Nation,from land promised to them by the federal government. The official Riding Mountain National Park information book details the so called "Master Plan" behind the development of the area, and specifically states that "public participation" was an important driver in its creation. ${ }^{3}$ Statements such as these echo the government's desire to distance itself from their direct participation in the development of parks and the disingenuous promises made to the Indigenous groups previously living in those areas. In 1906, the Keeseekoowenin nation were given land along Clear Lake to help sustain themselves through fishing and hunting, over time leading to the established a small permanent community developed of around eight families. Despite the fact that the Indian Act protected land given to a Band by requiring formal surrender (half the male population) to agree to succeed the land in question, governmental agencies were still able to force the Keeseekoowenin off of Clear lake. ${ }^{4}$ Increased efforts by groups advocating for the protection of game and the federal government's attempts to influence Indigenous populations towards agriculture, viewed as a more civilized mode of sustenance, ultimately meant that the Keeseekoowenin group living in the Clear Lake region were forced off of their land in what has been described as "our mini version of the trail of tears". 5

Through researching the existing academic literature surrounding this incident, what is perhaps most striking is the near total lack of acknowledgement that the Clear Lake eviction even took place. Scholarly work on the native experience in relation to the country's national parks has been slim, and the official Parks Canada website on Riding National Park carries only a brief acknowledgement that Ojibway groups "still live in the area today" along with a broken link to the Keeseekoowenin website. ${ }^{6}$ Another official Parks Canada publication focuses only on the

\footnotetext{
${ }^{1}$ Parks Canada, Riding Mountain National Park: Information. (Ottawa: The Department of Indian and Northern Affairs, 1974), 3.

${ }^{2}$ John Sandlos, "Not Wanted in the Boundary: The Expulsion of the Keeseekoowenin Ojibway Band from Riding Mountain National Park.” The Canadian HIstorical Review 2 (2008): 196, accessed March 14, 2016.

${ }^{3}$ Parks Canada, Riding Mountain National Park, 5.

${ }^{4}$ Sandlos, "Not Wanted in the Boundary", 203.

${ }^{5}$ Sandlos, "Not Wanted in the Boundary", 193.

6 “Riding Mountain National Park", accessed March 14, 2016, http://www.pc.gc.ca/eng/pn-np/mb/riding/natcul/natcul2.aspx.
} 
architectural legacy left by Indigenous groups, and both deliberately state that while the government was initially resistant to the idea of creating a national park at Riding Mountain, public opinion swayed them to designate the area. ${ }^{7}$ However, despite the strong conservationist push for disallowing Aboriginal groups to hunt, throughout the pre-agricultural period "no conflicts with humans were documented between elk and people". 8 This suggests that conservationism was only necessary because of the development of agriculture in the region following settlement by European migrants and not in relation to Indigenous hunting activity. Therefore economic welfare, and not conservationist ideals, was the major factor at play for the surrounding settler community. The importance that national parks carried for the economic development and social well being of the region was indicated in official documents which clearly stated that "as the mobility of the vacationing North American increases, visitors to Riding Mountain National Park can be expected to increase" and that "Riding Mountain National Park... continues to be a major source for recreational opportunities in the region". 9 Unfortunately the voices and opinions of Indigenous groups are entirely absent becaus earchival records "overwhelmingly privileges the voices of government administrators" at the expense of any dissenting voices. ${ }^{10}$ It therefore becomes increasingly difficult to juxtapose settler and aboriginal perspectives.

The erasure of Indigenous legacies is equally prominent in Banff National Park, where only token Indigenous memorabilia remains. Once again, the creation of Banff National Park is centered around a legacy of colonial exploitation and expropriation, accompanied by a general unwillingness to acknowledge the park's original inhabitants for fear of compromising its draw as a popular tourist destination. The area that is now Banff National Park was once promised to members of the Stoney Nakoda tribe, who subsisted primarily through hunting. Generally speaking, the displacement of the Nakoda people from the region closely mirrors the experience of the Keeseekoowenin Band. Through a process that entailed forced exposure to agriculture as an alternate means of subsistence, dissuasion from hunting and eventual expulsion from the region entirely, a clear pattern in the dealings between government officials and Indigenous populations emerges, one which streches beyond the examples of Riding Mountain National Park and Banff National Park. ${ }^{11}$ Once again "sportsmen certainly influenced these decisions more than any wilderness advocates", a dynamic that appears in many discussions surrounding the

\footnotetext{
${ }^{7}$ Parks Canada, Riding Mountain National Park of Canada, 13.

${ }^{8}$ Ryan K. Brook. "Historical Review of elk-agriculture conflicts in and around Riding Mountain National Park, Manitoba, Canada." Human Wildlife Interactions 21 (2009): 74, accessed March 16, 2016.

${ }^{9}$ Parks Canada, Riding Mountain National Park, 7.

${ }^{10}$ Sandlos, "Not Wanted in the Boundary", 200.

${ }^{11}$ Tolly Bradford, "A Useful Institution: William Twin, "Indianness," and Banff National Park, c. 1860-1940," Native Studies Review 16, no. 2 (2005): 82, accessed March 14, 2016.
} 
development of national parks. ${ }^{12}$ This argument is further strengthened by the argument made by Binnema and Niemi, who state that "those who pushed for the removal of Aboriginal people in Canada defended their arguments without even using the word or idea of wilderness", which proposes the view that ideals of conservation have likely been fabricated as later justification for the abolishment of Indigenous hunting rights, instead of their driving factor. ${ }^{13}$

The economic impact of Banff National Park for the surrounding region is even more apparent than Riding Mountain National Park. The use of Indigenous populations as spectacles to generate tourist revenue was evident in programs such as Indian Days, a practice that took place between 1890 and $1948 .{ }^{14}$ For a period of a few days members of the Nakoda band were asked to return to Banff to act as spectacles for tourists in order to promote the economic development of the surrounding region, after which the Indigenous actors were once again forced to vacate the park. In his article "Banff Indian Days affirmed stereotypes, reinforced culture", Alexander Rob wrote that "the popular literature used Banff Indian Days as evidence of Aboriginal support for the national parks and all that it stood for, when in fact, the largely positive narratives failed to consider how the national parks affected Aboriginal people”. Despite its muddied history, recent initiatives undertaken by Nakoda elders have since reinstated Banff Indian Days as a way to promote their own culture and not as a spectacle to be exported for tourism. ${ }^{15}$

Notwithstanding the history of largely contemptible action undertaken by the agencies of the Canadian Government, recent changes in policy may indicate that a fundamental shift is being undertaken in the relationship between Parks Canada and Aboriginal groups. Parks Canada states on their website that "including the voices of First Nations, Inuit and Métis peoples in the planning and management of heritage areas is now a common practice within Parks Canada", ultimately concluding that "Parks Canada sees the need to develop a framework to engage Aboriginal peoples in planning and managing national heritage areas by means of formal relationships with Aboriginal partners". ${ }^{16}$ While statements of policy should be read with a degree of scrutiny, this would propose that new methods of compromise between the two

\footnotetext{
${ }^{12}$ Theodore Binnema and Niemi Melaine, "Let the line be drawn now: Wilderness, Conservation, and the Exclusion of Aboriginal People from Banff National Park in Canada," Environmental History 11 (2006): 729, accessed March 14, 2016.

${ }^{13}$ Binnema and Niemi, "Let the line be drawn now," 724.

${ }^{14}$ Laurie Meijer Drees, "The Banff Indian Days," Native Studies Review 7 no. 2 (1991): 75. accessed March 14, 2016.

${ }^{15}$ Rob Alexander, "Banff Indian Days affirmed stereotypes, reinforced culture," Rocky Mountain Outlook, April 3, 2014, accessed March 14, 2015.

http://www.rmoutlook.com/Banff-Indian-Days-affirmed-stereotypes,-reinforced-culture-20140403

16 "Aboriginal Affairs Secretariat: Working Together, Our Stories," accessed March 14, 2016

http://www.pc.gc.ca/eng/agen/aa/te-wt/introduction.aspx/.
} 
previously opposing groups could lead to mutual respect and simultaneously accomplish both a return to traditional modes of subsistence and the maintenance of Canada's national parks.

This new language of cooperation is further supported by the events surrounding the Cape Breton moose culling. Several CBC news articles have documented an attempt at culling moose population within Cape Breton Highland National Park and the protests that succeeded in temporarily halting them. According to Derek Quann, "Parks Canada's resource conservation manager, Parks Canada, with its partners in the province, and the Mi'kmaq in Nova Scotia, have been monitoring this population quite closely for well over 15 years" and have discovered that a superabundance of moose are currently living within the National Park, leading to a decrease in pine sapling regrowth. ${ }^{17}$ Parks Canada has therefore decided to work with Mi'kmaq hunters in order to lower the moose population towards a stable level. ${ }^{18}$ Echoing past confrontations, a protest movement organized by the Nova Scotia Federation of Anglers and Hunters opposed the culling, although different protestors appeared to have different goals. While some carried signs declaring "Stop the Slaughter", others stated "Let's Hunt Together". Trina Roache offered her opinion that one of the driving factors behind the protest is that "[The protesters] didn't understand why the Mi'kmaq were in there, why it's not 50-50", and that "the Mi'kmaq, [are] not selling the meat, they're not making money off this... But there's a livelihood for the guides that happens there and they feel like that's getting cut into". ${ }^{19}$

While examples such as these remain the opinions of a single reporter, there nonetheless remains a number of similarities to past confrontations between Indigenous groups and local game hunters, both groups whose economic livelihood depends on hunting. This is strengthened by Binnema and Niemi's argument that historically, "because Aboriginal hunters offended the values of sport hunters in so many ways, and since sport hunters were so politically and economically influential and active, it is not surprising that sport hunters... were among the most important opponents of Aboriginal hunting rights". ${ }^{20}$ However, examples such as the Cape Breton Moose Culling suggest a fundamental shift in governmental agencies' willingness to defend the hunting rights of different Aboriginal groups as opposed to sport hunting groups. Furthermore, this situation represents a possible shift in the public opinion towards favouring Indigenous hunting rights over sport hunting groups. The most recent news articles suggest that

\footnotetext{
${ }^{17}$ Peggy MacDonald, "Cape Breton moose cull science strong, says Parks Canada," CBC News, November 9, 2015, accessed March 14, 2016, http://www.cbc.ca/news/canada/nova-scotia/moose-cull-highlands-hunters-1.3310496/.

${ }^{18}$ Wendy Marin, "Cape Breton moose cull to resume this fall, says Mi'kmaq chief," CBC News, November 13, 2015, accessed March 14, 2016, http://www.cbc.ca/news/canada/nova-scotia/moose-cull-cape-breton-1.3317593/.

${ }^{19}$ Peggy Macdonald, "What's really behind the Cape Breton moose cull protest? One reporter offers her views," CBC News, November 12, 2015, accessed March 14, 2016, http://www.cbc.ca/news/canada/nova-scotia/moose-hunt-aptn-reporter-1.3316069/.

${ }^{20}$ Binnema and Niemi, "Let the line be drawn now," 731.
} 
the moose cull was completed with the help of Mi'kmaq hunters, solidifying the government of Canada's willingness to work with Aboriginal groups to accomplish mutually beneficial goals. ${ }^{21}$

Ultimately, when looking at the treatment of Aboriginal rights in relation to national parks, one can see an evolution in the policies undertaken by government agencies. Although in cases such as Riding Mountain National Park and Banff National Park there is widespread evidence of destructive authoritarian practices, there is sufficient contemporary evidence to demonstrate the possibility of altering policy in favour of Aboriginal hunting rights rights. The recent cooperation between Parks Canada and Aboriginal groups demonstrates a renewed interest in the rights of Aboriginal groups. These rights have been enshrined in the UN Human Rights Committee in the late 20th century, which states that "necessary steps should be taken to restore and protect the titles and interests of Indigenous persons in their native lands", especially in regards to "traditional forms of economy". ${ }^{22}$ A willingness to cooperate offers the possibility of an expanded relationship between Parks Canada and different Indigenous groups, one that recognizes the mandate of Parks Canada to conserve protected areas of wilderness while simultaneously recognizing Indigenous hunting rights. Although hunting rights remain forbidden in certain national parks, cases such as the Cape Breton moose cull demonstrate ways in which the two previously opposing forces can cooperate in ways that are mutually beneficial.

\footnotetext{
${ }^{21}$ Peggy MacDonald, "Cape Breton moose cull to resume weeks after protests end first hunt," CBC news, December 1, 2015, accessed March 14, 2016. http://www.cbc.ca/news/canada/nova-scotia/cape-breton-moose-hunters-1.3345660

${ }^{22}$ Marcus Colchester, "Indigenous Peoples and Protected Areas: Rights, Principles and Practice," Nomadic Peoples

7 no 1 (2003): 26, accessed March 14, 2016
} 


\section{Bibliography}

“Aboriginal Affairs Secretariat: Working Together, Our Stories” Parks Canada. April 29, 2014. accessed March 14, 2016. http://www.pc.gc.ca/eng/agen/aa/te-wt/introduction.aspx Alexander, Rob. "Banff Indian Days affirmed stereotypes, reinforced culture .” Rocky Mountain Outlook. April 3, 2014. accessed March 14, 2016. accessed from http://www.rmoutlook.com/.

Binnema, Theodore, and Niemi, Melanie. "Let the line be drawn now: Wilderness, Conservation, and the Exclusion of Aboriginal People from Banff National Park in Canada." Environmental History, 11 (2006): 724-750. accessed March 14, 2016. accessed from https://www.ebscohost.com/

Bradford, Tolly. “A Useful Institution: William Twin,'Indianness,” and Banff National Park,c.1860-1940.” Native Studies Review 16, no. 2 (2005): 77-98. accessed March 14, 2016. accessed from https://www.ebscohost.com/

Brook, Ryan K. "Historical review of elk-agriculture conflicts in and around Riding Mountain National Park, Manitoba, Canada." Human Wildlife Interactions 21 (2009):72-87. accessed March 14, 2016. accessed from http://digitalcommons.unl.edu/

Buchik, Pat, and Mills, Edward, and Taylor, CJ. Riding Mountain National Park of Canada. Calgary: Parks Canada, 2001.

Colchester, Marcus. "Indigenous Peoples and Protected Areas: Rights, Principles and Practice." Nomadic Peoples 7, no. 1 (2003): 33-51. accessed March 14, 2016.. accessed from https://www.ebscohost.com/

Drees, Laurie Meijer. “The Banff Indian Days.” Native Studies Review 7 no. 2 (1991): 75-77. accessed March 14, 2016. accessed from http://iportal.usask.ca/.

MacDonald, Peggy. "Cape Breton moose cull science strong, says Parks Canada". CBC News. November 9, 2015. accessed March 14, 2016. http://www.cbc.ca/news/canada/nova-scotia/moose-cull-highlands-hunters-1.3310496.

MacDonald, Peggy. "Cape Breton moose to resume weeks after protests end first hunt". $C B C$ News. December 1, 2015. Accessed March 14, 2016. http://www.cbc.ca/news/canada/nova-scotia/cape-breton-moose-hunters- 1.3345660

Macdonald, Peggy. "What's really behind the Cape Breton moose cull protest? One reporter offers her views." CBC News. November 12, 2015. accessed March 14, 2016. http://www.cbc.ca/news/canada/nova-scotia/moose-hunt-aptn-reporter-1.3316069.

Martin, Wendy. "Cape Breton moose cull to resume this fall, says Mi'kmaq chief." $C B C$ News. November 13, 2015. accessed March 14, 2016. http://www.cbc.ca/news/canada/nova-scotia/moose-cull-cape-breton-1.3317593. 
Parks Canada. Riding Mountain National Park: Information. Ottawa: The Department of Indian and Northern Affairs, 1974.

Reichwein, PearlAnn. "Holiday at the Banff School of Fine Arts: The Cinematic Production of Culture, Nature, and Nation in the Canadian Rockies, 1945-1952.“Journal of Canadian Studies 39, no. 1 (2005): 49-73. accessed March 14, 2016. accessed from https://www.ebscohost.com/

“Riding Mountain National Park.” Parks Canada. January 29, 2014. accessed March 14, 2016. http://www.pc.gc.ca/eng/pn-np/mb/riding/natcul/natcul2.aspx

Sandlos, John. "Not Wanted in the Boundary: The Expulsion of the Keeseekoowenin Ojibway Band from Riding Mountain National Park." The Canadian Historical Review no. 2 (2008): 189. accessed March 14, 2016. accessed from https://www.ebscohost.com/. 